\title{
Dr Wu Lien-teh: modernising post-1911 China's public health service
}

\author{
Kam Hing Lee $\underline{e}^{1}$, MA, PhD, Danny Tze-ken Wong${ }^{2}$, MA, PhD, Tak Ming $\underline{H o}^{3}$, MBBS, FAFP, Kwan Hoong $\underline{\mathrm{Ng}}{ }^{4}$, PhD, FlnstP
}

\section{INTRODUCTION}

A young Chinese doctor from a small British colony gaining fame for his role in ending a pneumonic plague in faraway north-east China is indeed a remarkable story. Wu Lien-teh (1879-1960), although standing at only 5 feet 2 inches, short even by Chinese standards, towered over many of his contemporaries because of his dedicated medical work. He was also prominent in the advancement of social and cultural causes. In particular, he campaigned against the opium trade, which had caused irreparable harm to health in China and Southeast Asia.

Beyond his battle against the pneumonic plague in Manchuria, Wu was also in the forefront of efforts to create a modern public health service in China. His efforts helped China regain control of quarantine centres in all major ports that had come under the supervision of foreign powers. Wu was also called to deal with the cholera epidemic in China's north-east region in 1920-21. Active in international conferences and research, Wu was the first Chinese to have his work published in the prestigious medical journal, Lancet.

For his contributions, Wu was conferred honorary doctorates by Peking University, Hong Kong University and Tokyo University. In 1935, he was nominated for the Nobel prize for his fight against the 1910 Manchurian plague and for identifying the role of tarbagan marmots in the transmission of the disease. ${ }^{(1)}$ The epidemic, one of the deadliest of its kind, killed an estimated 60,000 people in the affected regions of Manchuria during the seven months that it lasted.

\section{BACKGROUND OF WU}

Originally named Ngoh Lean Tuck, Wu changed his name to 'Wu Lien-teh' when he travelled to China in 1908. He was born in Penang, Malaya, in 1879. His father, a goldsmith, came from Taishan, China. ${ }^{(2)} \mathrm{Wu}$ studied at the premier Penang Free School, and after winning the prestigious Queen's Scholarship, enrolled at Emmanuel College, Cambridge, in 1896. ${ }^{(3)} \mathrm{Wu}$ was the first Chinese to graduate in medicine from Cambridge. He did a year of postgraduate research on bacteriology at the School of Tropical Medicine, Liverpool, under Sir Ronald Ross (Nobel Laureate for Physiology in 1902). He then proceeded to the Pasteur Institute, Paris, to research on malaria and tetanus. ${ }^{(4)}$
Returning to Malaya in 1903, Wu was welcomed into local high society. He was invited to give public lectures in Singapore, and there, he formed a friendship with Dr Lim Boon Keng and Song Ong Siang. Lim was a well-known doctor and a businessman who was deeply involved in social reforms. Wu joined Lim and Song in editing The Straits Chinese Magazine, a learned journal on cultural and social issues for the small but influential Straits Chinese community. ${ }^{(5)}$ In Singapore, Wu met Ruth Shu-chiung Huang, daughter of Wong Nai Siong, a Confucian scholar who helped Fuzhou Christians settle in Sarawak. Wu married Ruth, whose sister was the wife of Dr Lim Boon Keng.

Meanwhile, Wu joined the Institute for Medical Research in Kuala Lumpur to investigate beriberi, a disease that afflicted thousands of Chinese tin miners. ${ }^{(6)}$ Not long after, he went into private practice in Penang. However, Wu was troubled by the widespread addiction to opium, especially among the Chinese labouring class, and so he joined a nationwide campaign against the distribution and use of opium. At that time, proceeds from the sale of opium contributed substantially to colonial revenue in Malaya. Wu founded the Anti-Opium Association in Penang, and in March 1906, he organised a nationwide anti-opium conference in Ipoh, which was attended by about 3,000 participants. ${ }^{(6)}$

However, an event happened, changing the course of Wu's life. In early 1907, Wu was charged and fined in court for possession of an ounce (about $28 \mathrm{~g}$ ) of opium tincture in his clinic. ${ }^{(7)}$ In his defence, Wu claimed that the cupboard in which the drug was found came with the clinic he had bought from a British lady doctor. It is not clear whether the case had anything to do with his anti-opium campaign, but Wu felt bitter and humiliated.

At this juncture, Wu received an invitation to serve in China. A few months earlier, a group of young Chinese sent by the Qing government on an overseas study tour had stopped at Penang. Wu met one of them, a Cornell University graduate named Saoke Alfred Sze, who was later to become China's Councillor of Foreign Affairs. Through Sze, Wu developed friendships with other influential Chinese. Wu's ability to build long-term relationships with people whom he respected eventually led to his invitation to China. In May 1908, Wu sailed with his wife, first to Shanghai, then to Tianjin. There, he was introduced

\footnotetext{
${ }^{1}$ Social and Behavioural Sciences Research Cluster, ${ }^{2}$ History Department and Malaysian Chinese Research Centre, University of Malaya, Kuala Lumpur, ${ }^{3}$ Perak Academy, Ipoh, ${ }^{4}$ Faculty of Medicine, University of Malaya, Kuala Lumpur, Malaysia 
to the Manchu Chief of the Army Services who, greatly impressed by $\mathrm{Wu}$, made him vice director of the Imperial Army College in Tianjin. ${ }^{(8)}$

\section{WU AND THE PLAGUE}

Just as Wu was settling into a routine in Tianjin, he was called upon to deal with a health crisis. In the autumn of 1910, reports reached Beijing that a deadly disease had broken out in Fuchiatien (Fujiandian), the Chinese sector of Harbin in northern Manchuria. Those who were infected with the disease coughed up blood-streaked sputum and had purplish discolouration of the skin. Death followed within a few days. The first victims of the pneumonic plague were marmot trappers and fur traders in Manzhouli, along the Siberian border. ${ }^{(9)}$

The epidemic was brought on by an unusual combination of circumstances. There was, at this time, a growing demand in the West for the pelt of marmots and wild rodents found in Manchuria and Siberia, as the thick fur could pass for sable when suitably dyed. This flourishing trade brought in a large number of emigrant hunters from Shandong, and by September 1910, there were about 10,000 hunters in the forests of Manchuria. Local hunters were aware that healthy marmots roam open fields emitting a shrill cry, whereas sick marmots are mute and stay inside their burrows to die. However, many new hunters, anxious to collect enough pelts, dug out sick marmots from their burrows. ${ }^{(10)}$

On 19 December 1910, the Chinese government instructed $\mathrm{Wu}$ to head for the plague-affected areas. With the approaching Lunar New Year celebrations, there was a risk of the epidemic spreading when individuals from plagueaffected areas travelled to their hometowns in different regions. ${ }^{(11)}$ Five days later, Wu and his assistant arrived in Harbin late on a cold afternoon. Wu faced difficulty in conducting postmortems on plague victims, as the procedure was generally unacceptable in China then. Quite fortuitously, Wu learnt on the third day of his arrival that the Japanese wife of a Chinese had fallen victim to the plague the day before. Wu was thus able to perform a postmortem, the first ever done in China. From this and subsequent postmortems, Wu found that the bacillus isolated and cultured by bacteriologists was identical to Bacillus pestis, which had been isolated from previous epidemics of bubonic plague. The strain isolated in Harbin was of a highly virulent type, rapidly producing septicaemic plague. ${ }^{(12)}$

On 11 January, a medical professor from Peiyang Medical College in Tientsin became a victim of the plague. The French doctor, remembered only as Dr Mesny, had arrived a few days earlier with the intention to replace $\mathrm{Wu}$ as head of the Chinese operations. He had visited a hospital without the protection of a face mask. Although news of the death of a member of the Chinese medical team caused near panic in Harbin, it also galvanised the Chinese and foreign governments into urgent action. $^{(13)}$
The decisive $\mathrm{Wu}$ advised that movement of the population be curtailed; he instructed that plague victims be hospitalised, their homes disinfected and contact prohibited. People were encouraged to wear gauze-and-cotton masks. A new plague hospital was built and the old one was burnt down. The Chinese government sent volunteer doctors and about 1,200 soldiers to monitor the movements of the population, especially on railways, where a large number of terror-stricken people were trying to leave the city; 600 police were also mobilised to assist in the door-to-door search for those who were affected. Russian authorities loaned 120 freight cars to house those who had contracted the disease. Despite this rescue effort, the mortality rate continued to rise. All who contracted the disease eventually died, and Fuchiatien lost a quarter of its population. $^{(13)}$

In late January 1911, Wu was horrified to discover over 2,000 unburied bodies. It was midwinter and the ground was frozen solid, but Wu feared that when spring brought warmer weather, the dead bodies could pose a serious public health risk. Rats rummaging among the bodies could also spread the infection. Mass cremation was the solution, but the Chinese viewed this as an act of desecration. To overcome this problem, Wu invited local officials to visit the burial ground and explained to them the health dangers. Then he sent a memorandum to the Emperor. After three anxious days, the Imperial Edict allowing cremation arrived. On 31 January 1911, the Chinese Lunar New Year, the first mass cremation in Chinese history began. Bodies that had been previously buried were also dug up and cremated.(14) Eventually, the mortality figures started to decline and the disease ran its course. On 1 March 1911, the last case of plague was recorded. Altogether, the epidemic had lasted seven months.

\section{WU AND CHINA'S PUBLIC HEALTH SERVICE}

Before long, Wu had to deal with international reaction to the Manchurian plague. The plague was a matter of great international concern, with fears that the disease could spread across borders. Harbin and neighbouring Fuchiatien in Manchuria were near the Russian border. In April 1911, an urgent international conference was called in Mukden (now Shenyang) to discuss the epidemic, and $\mathrm{Wu}$ was tasked with leading the China delegation. Participants came from 11 nations, including Japan, the United States and Britain. With his Cambridge training, international research experience and a reputation enhanced by the Manchurian plague campaign, Wu played a major role in the conference proceedings, including chairing the plenary sessions. ${ }^{(12)}$

Wu remained in China during its most tumultuous period during the 1911 revolution and civil war years. In June 1913, Wu met Yuan Shi-kai, who had succeeded Sun Yat-sen as president of the new republic. Impressed by $\mathrm{Wu}$, Yuan appointed him as one of his consulting physicians. However, Wu had other responsibilities in China. The plague and its resulting international 
implications convinced leaders of post-1911 China that a western-type public health service was a necessary foundation for a modern state. As a first step toward a public health service, the North Manchurian Plague Prevention Service was set up with $\mathrm{Wu}$ as the director. The Service, under $\mathrm{Wu}$, who was assisted by a number of overseas trained medical staff, embarked on clinical work, health education and medical research. ${ }^{(15)} \mathrm{A}$ major health figure now, Wu was called upon to serve in two other important organisations set up by the new Chinese government. In 1915, the National Medical Association was formed to promote western medicine in China. Wu was elected secretary in 1915, and president in 1916-1920.

In 1930, the Chinese government created the National Quarantine Service (NQS) and appointed Wu as its first director. Headquartered in Shanghai and staffed by Chinese personnel, NQS enabled the Chinese government to regain quarantine control of all major ports in China. The NQS was linked by cable to the League of Nation's Eastern Bureau of the Health Service, and weekly reports were sent to the League's Epidemiology Section. Following this, Wu was made a member of the Advisory Board of the League's Far Eastern Epidemic Bureau. ${ }^{(16)}$

Wu noted that traditional Chinese medicine practitioners were resistant to the modernisation of China's health service. Trained in western medicine, $\mathrm{Wu}$ had regarded traditional Chinese medicine to be only of historical and cultural value. Nevertheless, he was always attentive to local sensitivities, urging that the study of medicine in China should embrace both the traditional healing system and modern medicine.

\section{THE LEGACY OF WU}

In 1937, as Japanese troops advanced into China, Wu left for Malaya and never saw China again. War and the change in regime made it impossible for $\mathrm{Wu}$ to return to the land where he had served so devotedly for almost 30 years and suffered personal losses. His wife, Ruth, and two of his three sons had died of ill-health in China. Wu later remarried and had a new family of four children and his surviving son from the first marriage. On his return to Malaya, he opened a private clinic in Ipoh, where he provided free medical treatment for the poor.

Wu had close brushes with danger throughout the course of his work. In November 1931, while in the Japanese-controlled sector of Manchuria, Wu was detained and interrogated as a Chinese spy by the Japanese authorities. In 1943, he was seized by members of the left-wing resistance movement in Malaya and was only released from jungle captivity near Ipoh after a ransom was paid. Unfortunately, the Japanese authorities found out about the ransom payment and accused him of aiding the resistance movement. Wu was saved on these occasions due to his medical credentials and because he was the attending physician of one the Japanese officers in Malaya. ${ }^{(2)}$

One of Wu's lasting legacies was his research work, which he was able to leave behind for other researchers to build upon.
His research and papers presented in overseas conferences were published in national and international journals, including the National Medical Journal of China's National Medical Association, and Lancet. In all, he published over 92 papers, including 31 on the subject of plague, and numerous papers on other infectious diseases, public health, narcotics and medical history. ${ }^{(17)} \mathrm{Wu}$ was also the co-author of the massive History of Chinese Medicine, which was published in China in 1932. ${ }^{(18)}$

More than a doctor, Wu had strong literary interests. Between 1895 and 1905, he co-edited The Straits Chinese Magazine, a journal of arts, science and society. In China, he collected paintings and other works of art. Always interested in books and learning, he helped set up the Perak state library and made a personal donation to it. Wu gave generously to institutions of learning, donating a small library of ancient Chinese medical titles as well as his house in Beijing to the China Medical Association. Similar donations of books were made to the Shanghai City Library and University of Hong Kong. The 2,000 books that he gave to Nanyang University became the Wu Lien-teh Collection. He also left six of his treasured paintings with the Art Museum of the University of Malaya.

His sense of gratitude to the British prevailed over whatever bitterness he might have had after his conviction of opium possession in colonial Malaya. He contributed 3,000 British pound sterling to the China Branch of the Royal Asiatic Society, an institution set up by British residents in Shanghai to promote understanding of Western and Chinese civilisations because he "had largely reached [his] present position through early opportunities offered by the British Government in the way of scholarships and university education"..(2) In 1956, Wu made a trip back to Emmanuel College, Cambridge, where his medical journey first started. In 1959, he completed his autobiography. A year later, Wu passed away. ${ }^{(19)}$

Wu gained international fame when he helped bring the Manchurian plague under control. He was at the forefront of China's engagement with the international medical community. His Cambridge training enabled him to mediate the medical approaches of Chinese and Western scientists. More importantly, Wu brought with him an outsider's perspective, free from the tradition of China's medical practices, but as an overseas Chinese, he stood with China's quest for modernity through western medicine.

\section{REFERENCES}

1. The Nomination Database for the Nobel Prize in Physiology or Medicine, 1901-1953 [online]. Available at: http://www.nobelprize.org/nomination/ medicine/nomination.php?action=show\&showid=1229. Accessed August 1, 2013.

2. Wu LT. Plague fighter: the autobiography of a modern Chinese physician. Cambridge: W Heffer and Sons Ltd, 1959: 134-5, 622-5.

3. Further success for Mr Ngoh Lean Tuck, The Singapore Free Press 1899 July $19 ; 3$

4. Venn J, Venn JA eds. Tuck, Gnoh Lean (Wu Lien-Teh). Alumni Cantabrigienses (10 vols) (1922-1958) [online]. Cambridge University Press. Available at: http://venn.lib.cam.ac.uk/cgi-bin/search.pl?sur=\&sur $\mathrm{O}=\mathrm{c} \& \mathrm{fir}=\&$ firo $=\mathrm{c} \& \mathrm{cit}=\& \mathrm{cito}=\mathrm{c} \& \mathrm{c}=\mathrm{all} \& \mathrm{tex}=\mathrm{TK}$ 896GL $\&$ sye $=\&$ eye $=\& \mathrm{col}=$ all\&maxcount=50. Accessed August 2, 2013. 
5. Frost MR. Emporium in imperio: Nanyang networks and the Straits Chinese in Singapore, 1819-1914. J Southeast Asian Studies 2005; 36:29-68.

6. Ho TM. Doctors Extraordinaire. Ipoh: Perak Academy, 2006: 57-76.

7. Penang Doctor Fined: Brief outline of the defence of Dr Tuck/ The Straits Times, 1908 March 5; 7

8. Wu XK. Dr Wu Lian-teh, renowned epidemiologist and pioneer of modern health work in China. Chinese Med J 1987; 100:509-17.

9. Farrar R. Plague in Manchuria. Proc R Soc Med, 1912; 5:1-24.

10. Wu LT. Investigation into the relationship of the Tarbagan (Mongolian marmott) to plague. Lancet 1913; 182:529-35.

11. Chernin E. Richard Pearson Strong and the Manchurian epidemic of pneumonic plague, 1910-1911. J His Med Allied Sci 1989; 44:296-319.

12. Wu LT Inaugural address on plague (Delivered at the International Plague
Conference, Mukden on April 4, 1911). Lancet 1911; 177:1117-8.

13. Gamsa M. The epidemic of pneumonia plague in Manchuria 1910-1911. Past and Present February 2006; 190:147-84.

14. Mates LH. Lien-Teh Wu. In: Davies D, Mates LH, eds. The Encyclopaedia of Cremation. Burlington: Ashgate, 2005: 300-1.

15. Flohr $\mathrm{C}$. The plague fighter: Wu Lien-teh and the beginning of the Chinese public health system. Annals of Science 1996; 53:361-80.

16. Yang S. Dr Wu Lien-teh and the national maritime quarantine service of China in 1930s. Zhonghua Yi Shi Za Zhi 1988; 18:29-32.

17. Wu LT. The menace of morphine to China. Lancet 1917; 189:874-5.

18. Wu LT, Wong KC. History of Chinese Medicine: Being a Chronicle of Medicine Happenings in China from Ancient Time to the Present. 2nd ed. Shanghai: National Quarantine Services, 1932.

19. Obituary: Wu Lien-teh. Br Med J 1960; 1:429-30. 